Article

\title{
Between Self-Regulation and Participatory Monitoring: Comparing Digital News Media Accountability Practices in Spain
}

\author{
Pedro-Luis Pérez-Díaz ${ }^{1, *}$, Rocío Zamora Medina ${ }^{2}$ and Enrique Arroyas Langa ${ }^{1}$ \\ ${ }^{1}$ Department of Journalism, Catholic University of Murcia, 30107 Murcia, Spain; E-Mails: plperez@ucam.edu (P.-L.P.D.), \\ earroyas@ucam.edu (E.A.L.) \\ 2 Department of Journalism, University of Murcia, 30100 Murcia, Spain; E-Mail: rzamoramedina@um.es \\ * Corresponding author
}

Submitted: 15 December 2019 | Accepted: 5 February 2020 | Published: 16 April 2020

\begin{abstract}
In recent years, the accountability practices of digital journalism have gone from constituting an intimate and self-regulatory system of journalistic culture to a complex process that is increasingly external and open to the public (Fengler, Eberwein, Mazzoleni, Porlezza, \& Russ-Mohl, 2014; Suárez-Villegas, Rodríguez-Martínez, Mauri-Ríos, \& López-Meri, 2017). In this context, values and goals may remain diverse, arguably linked to idiosyncratic elements which often open a gap between traditional and more contemporary newsroom models. Following a qualitative approach, this study examines online media accountability instruments from a functional perspective, dividing its influence in three temporal phases of news production (Heikkilä et al., 2012). In this way, instruments that hold journalists responsible for their work are explored in four leading online news media from Spain: two digital native outlets (Eldiario.es and ElConfidencial.com) and two legacy outlets (EIPais.com and EIMundo.es). In addition to this observation, in-depth interviews are conducted with staff members in charge of audience management to explore the inner routines and protocols that determine the efficacy of such aspirations. Our work reveals the preponderant role of instruments focused on the actor and production transparency that the studied media implement to fulfill their responsibility, especially when compared with the weakened self-regulation instruments. The answers of the interviewees stress the difficulties they face in managing participatory forms of accountability and disclose tensions between different strategies, as well as other structural factors that are discussed as essential for the consolidation of these deontological initiatives.
\end{abstract}

\section{Keywords}

citizen participation; deontology; digital journalism; journalism ethics; journalistic culture; media accountability; self-regulation; transparency

\section{Issue}

This article is part of the issue “Digital Native News Media: Trends and Challenges" edited by Ramón Salaverría (University of Navarra, Spain).

(C) 2020 by the authors; licensee Cogitatio (Lisbon, Portugal). This article is licensed under a Creative Commons Attribution 4.0 International License (CC BY).

\section{Introduction}

The accountability of the media is a normative concept on which attempts to balance media freedom and responsibility with society converge; a process that defines "how the media answer, to whom and for what" (Min, 2015, p. 1). As in the early 1940s, the Hutchins Commission's report suggested that press freedom should be subject to the media's commitment to provide a public service that, from professional ethics, overcomes the limitations and defects of the liberal paradigm inspired by Mill, in which the freedom of the market is the best guarantee for the free circulation of ideas. Besides, media must evaluate the considerations provided in constitutions, bodies of laws and other forms of public regulation that, in democratic societies, ensure the correction of these distortions. Media accountability based on legal texts is usually particularly effective in 
the protection of individual rights, "when property is involved and where liability for specific forms of harm to an individual is at issue" (McQuail, 2003, p. 266).

To safeguard their autonomy from political and economic influence, journalistic organizations promote their own media accountability systems, understood as "any non-state means of making media responsible to the public" (Bertrand, 2000, p. 108) through techniques such as training, evaluation, monitoring and feedback. Thanks to them, they improve their public image and raise quality standards, through a set of voluntary practices that compel them to act according to self-regulation principles and structures, especially before internal peers of the organization itself, but also before external professional bodies (McQuail, 2003). In the complex context in which contemporary journalism develops, selfregulation is not only the way in which news institutions protect their activity from the interference of external powers, but also serves to preserve trust, the true social capital of journalism (Fengler, 2012).

This professional accountability is complemented by a public accountability that seeks to invigorate the links with the citizens, offering answers and collaborative ways for coregulation, and it is in this sense that it "encompasses inviting dialogue with the public about journalistic behavior" (Friend \& Singer, 2015, p. xix). Audiences using digital platforms are not only information recipients, but they also actively interact, debate, create, communicate, and share information. In this way, active and conscious audiences can play an influential role in holding the media accountable to professional and public stakeholders by monitoring and criticizing whether media content follows ethical standards and journalistic values, and honors audience interests (Bhakta Acharya, 2015).

The media ecosystem that emerges after the 'participatory turn,' where anyone can publish, increases the need to legitimize journalistic work, which leads to the radicalization and exacerbation of media accountability instruments (MAls) and transparency efforts (Eide, 2017) of which digital media take advantage (Fengler, Eberwein, Mazzoleni, Porlezza, \& Russ-Mohl, 2014). While MAls can be effective in checking whether news organizations and their journalists act in accordance with professional standards, showing in a transparent manner the details of the newsmaking process would contribute to consolidating their credibility. However, good journalism, like other democratic practices, often involves non-transparent activities-such as refusing to disclose sources-so professional ethics should not be restricted to a culture of transparency (Ward, 2013).

The framework of assumptions and norms of predigital journalistic ethics in which these practices are based remains fully valid in the digital scenario (García-Avilés, 2014), in which the initial paradigm of social responsibility that was born with the Hutchins Commission (focused on limitation) has turned toward a new one in which citizen participation emerges as an amendment to the inefficiencies of traditional mechanisms (Palau-Sampio, 2017). Of course, audienceinclusive models of accountability enhance one of the main weaknesses of self-regulation mechanisms, by giving space to that fraction of the audience that has sufficient interest to evaluate the journalistic performance. As a result, individual and organizational profiles on social media convey forms of contact and publications that invite readers to be involved in these participatory monitoring tasks, which entails a marginal cost in terms of individual effort, but which, cumulatively, can impact greatly on the professionals' routines (Fengler, 2012). In 2017, the publisher of The New York Times, Arthur Sulzberger, justified the disappearance of its ombudsperson after 15 years of activity referring precisely to the competencies of digital citizenship: "Today, our followers on social media and our readers across the Internet have come together to collectively serve as a modern watchdog, more vigilant and forceful than one person could ever be" (as cited in Gold \& Pompeo, 2017).

\section{MAls in the Spanish Online News Media Context}

MAls have been present in the Spanish digital news media since their birth in the mid-1990s, and this digital environment has favored the presence of certain instruments focused on self-regulation, transparency and supervision of information quality, in which the participation of users plays a decisive role (Mauri-Ríos \& Ramon-Vegas, 2015; Suárez-Villegas, Rodríguez-Martínez, Mauri-Ríos, \& López-Meri, 2017). The Spanish media ecosystem showed in previous research a lack of collective concern to advance in this area (Campos-Domínguez \& Redondo-García, 2016), consistent, in turn, with the perception among journalists themselves, who doubt that online news media better serve accountability than legacy ones (Suárez-Villegas, 2015). Thus, the national situation was initially characterized by the low impact of these practices and their limited use by citizens (Alsius \& Salgado, 2010), within an "asymmetric landscape" (Alsius, Mauri-Ríos, \& Rodríguez-Martínez, 2011) that is a result of the different journalistic cultures that still coexist today in this territory (Suárez-Villegas et al., 2017).

All these deontological initiatives always seem modeled "by the social, technological, and economic structure of news media" (Ward, 2015, p. 347), factors that, precisely, often differentiate many newer digital-born news media from well-established legacy media. Spain has a rich and dynamic digital news scene: of the national online media active in 2018, 35\% were digital natives compared to $50.9 \%$ legacy outlets (Salaverría, Martínez-Costa, \& Breiner, 2018). Many of the native ones were born in a scenario of economic crisis that proved catastrophic for the sector, but led to the birth of 579 new outlets between 2008 and 2015 (Asociación de la Prensa de Madrid, 2015); most of them digital and launched by journalists as a form of self-employment. 
These forms of entrepreneurial journalism brought with them "new business styles based on greater social responsibility and greater transparency, which involve the online publication of accounting reports distancing themselves from legacy news companies characterized by opacity" (Casero-Ripollés, 2016). In fact, projects born on the Internet often opt for a younger staff formed of tech-savvy digital natives who develop audience-centric models of journalism (Wu, 2017) and a more open attitude toward citizen participation than legacy organizations and practitioners (Domingo, 2015). Regardless of digital news media types, all MAls can be classified according to the moment of the news production process they affect (Heikkilä et al., 2012): before production, during production, and after publication.

Before production, news organizations arrange a constellation of spaces in which they make public all kinds of corporate information that serves to improve their transparency as media actors. Some of them also make available to the public their ethical codes and style guides, initially conceived as documents for internal use, which acquire new possibilities of dissemination and update thanks to the Internet and a public projection superior to the obsolescent printed editions (Rojas Torrijos \& Ramon-Vegas, 2017). Another formula timidly explored in the country is the spaces dedicated to economic transparency that treasure potential to verify editorial independence, an option that has gained strength after the irruption of the reader-funded business models present in the Spanish market since the beginning of the decade of the 2010s (García-Avilés \& Arias Robles, 2016).

During production, digital news media offer different instruments to make their activity and ways of working visible, so as to increase transparency in their news production. Thus, it is common for each news story to have a whole series of indicators that reveal crucial aspects about the creators of the article (bylines/author's previous publications), its temporal validity (timestamps/updates) or its soundness (links to sources). Among the initiatives that demolish the fourth wall of their workspace, the newsroom blogs have been slowly adopted by the Spanish outlets due to the effort and time they require, not always properly recognized (García-Avilés, 2019). In the most radical approach, the opening of news production can be materialized in collaborative content, in which journalists proactively request user-generated content to nourish their pieces, something that in Spain has often been done without the guidance of clear strategies (Masip \& Suau, 2014).

After publication, there are possibilities for dialogue with the public that demonstrate the organization's responsiveness. At this stage, established instruments from the offline world are renewed, such as letters to editors, which on the Internet are not restricted by paper space limitations (Pastor, 2011); or as the ombudsperson that manages reader complaints, still present in four prestigious Spanish newspapers (Alsius, Rodríguez-Martínez, \& Mauri-Ríos, 2018). For their part, e-mail and web forms are the most basic private channels in which readers express their demands for professional responsibility, although on other occasions these interventions arise publicly, in spaces where a community emerges, and that in Spain began to originate in discussion forums and blog zones. Ultimately, online comments ended up prevailing as a standard of feedback that the academic literature describes as a potential instrument for holding news media responsible (Craft, Vos, \& David Wolfgang, 2016; Heikkilä et al., 2012). However, in Western European countries like Spain they have been frequently harmed by their "sheer volume..., their spontaneity and unruliness" that has led to online news media dealing with poor quality comments, in which hate speech and violations of people's dignity "are not infrequent" (Heikkilä et al., 2012, p. 59).

Beyond the internally driven online MAls offered on the websites, social media arise as the most prominent external digital spaces in which journalists and media brands can engage and take responsibility for their work before the 'crowd-criticism.' Journalists share this arena with an active audience that can overcome the limitations and indulgences of professionals as watchdogs of their own work: "We can assume that media users interested in the quality of journalism have no...incentives to remain in good terms with media professionals, and thus can fully exploit their sanctioning power" (Fengler, 2012, p. 186). In this sense, the Spanish journalists do not employ peer criticism to the same degree as their international colleagues (Rodríguez-Martínez, Mauri-Ríos, \& Fedele, 2017), and they feel more responsible to their conscience, codes of ethics or their sources than to the audience (Chaparro-Domínguez, Suárez-Villegas, \& Rodríguez-Martínez, 2019).

\section{Research Questions and Methods}

This work presents a qualitative research analysis of the online MAls driven in internal and external digital spaces by a sample composed of the most visited generalinterest digital news media in Spain, according to the weekly audience results in the Reuters Institute's Digital News Report Spain (Negredo, 2019). Thus, our strategic selection included the online editions of two newspapers (EIPais.com and EIMundo.es) and two online-only outlets (Eldiario.es and ElConfidencial.com). This study seeks answers to the following questions:

RQ1: What kind of online MAls are being implemented by these digital news outlets?

RQ2: What internal routines, protocols and perceptions determine the effectiveness of such instruments?

RQ3: Are there significant differences between the adoption of these instruments in digital native and legacy media? 
To respond to RQ1, we compiled the digital instruments classified in previous research (Fengler et al., 2014; Suárez-Villegas et al., 2017), which were added to our analysis by a snowball sampling technique (Goodman, 1961) until reaching a total of 15 online MAls present on the website of each outlet, articulated in the three phases described in our theoretical framework (Heikkilä et al., 2012). During alternate weeks of the first six months of 2018, we applied a qualitative content analysis (Krippendorff, 2004) using a code sheet focused on performance categories (frequency, function and visible results) for these mechanisms, which were classified according to their nature, using the distinctions previously established in the literature (Mauri-Ríos \& Ramon-Vegas, 2015; Suárez-Villegas et al., 2017): selfregulation $(S)$, transparency $(T)$, and participatory monitoring $(P)$. Finally, each instrument received a rating based on their level of implementation: consistently implemented (•, 1 pt.), irregularly implemented (o, 0.5 pt.) or not implemented at all ( $\times, 0$ pt.). The quantification of these variables allowed us to visualize the implementation of MAls using Kiviat diagrams, two-dimensional charts where these metrics were represented with points on axes that start from the same central coordinate and that, connected to each other, draw useful areas for comparative purposes.

In order to address RQ2, we conducted telephone in-depth interviews with the journalists who lead the audience engagement teams in these digital news media and are in charge of a staff of 12 editors (Raquel Seco, El País), 5 (Santiago Saiz, El Mundo), 9 (Ander Oliden, El Diario), and 3 (Álvaro Rigal, El Confidencial). From a semi-structured and exploratory questionnaire, we asked open questions about the MAls in which their opinions, perceptions or knowledge structures were requested. We organized the questions around thematic blocks according to our study premises and formulated them in an order that flowed from general, simple or descriptive questions to those more complex or sensitive that required evaluations (Hernández Sampieri, Fernández Collado, \& Baptista Lucio, 2010, p. 421). Those questions revolved around daily tasks ("Is the correction of errors reported by the audience properly carried out?"), customs ("Is there any limitation when linking to news sources?"), and viewpoints ("In your opinion, what is the general feeling of your organization towards the implementation of social media guidelines?").

To achieve the comparative results expected in RQ3, we contrasted the qualitative (and later quantified) results obtained from our content analysis by distinguishing them according to the nature of each outlet (legacy/native), in the same way that we brought the statements of their respective interviewees together. In order to outline the leading outlets for which these journalists work, a brief contextual description of each of them is given below. ElPais.com is the digital edition of the best-selling general-interest daily in Spain, which has been present on the Internet since 1996. In the next decade, this outlet assumed immediacy, multimedia and citizen participation, but also experimented unsuccessfully with a paywall. In 2010, it incorporated an internal social network, Eskup, and two years later, it became the world leader in Spanish-language news. After changing its slogan to "The Global Newspaper in Spanish," it tried to expand its reach with the launch of specific editions for America, Brazil, Catalonia and the English-speaking public. Its main competitor, El Mundo, launched its online edition in 1995 and developed a digital newsroom formed by a team of pioneers who left for El País in 2000. ElMundo.es underwent major redesigns linked to digital innovation and the improvement of its accessibility in 2009, 2015 and 2019. In 2010, the newspaper's parent group began distributing its contents on a digital newsstand called Orbyt, based on a freemium business strategy.

The most read native online news outlet in the country is Eldiario.es, founded in 2012 by a group of journalists who own more than $70 \%$ of the outlet and among which is its Editor-in-Chief, author of the wellknown political blog Escolar.net. This outlet is characterized by prioritizing alternative informative approaches and sections, a rapid technological adaptation and a policy of alliances and acquisitions of other media brands, added to a wide network of regional branches throughout the country. Its business model is based on subscribers ('partners') as a complement to advertising. Finally, ElConfidencial.com is a veteran player that was born in 2001, in the midst of the dotcom crisis, as a digital native news site inspired by the old and influential newsletters. Initially focused on economic issues aimed at an exclusive audience, six years later it evolved into a project with a general-interest ambition with which it achieved sustained growth, supported by an innovation laboratory that experiments with ideas and formats such as data journalism or major investigations in collaboration with the International Consortium of Investigative Journalists.

\section{Online Media Accountability Practices}

\subsection{Before Production}

We include here the online media accountability practices before production, which mean to consider not only those practices directly related to content production but reflected on the accountability of the organization, its structure, and its business practices. Publishing corporate information is a transparency instrument fully incorporated in the analyzed news media (see Table 1); all of them offer information about their owners through a static web page that can always be accessed from the bottom of the homepage, as is the case with the organigrams that, in the manner of mastheads, are widely used to present those who hold important positions within the staff. As for the detailed rosters of these outlets' sources of finance, they remain veiled with the excep- 
Table 1. Level of implementation of MAls that have an impact before news production.

\begin{tabular}{lcccc}
\hline MAI & ElPais.com & ElMundo.es & Eldiario.es & ElConfidencial.com \\
\hline Corporate information (T) & $\bullet$ & $\bullet$ & $\bullet$ & $\bullet$ \\
Staff structure (T) & $\bullet$ & $\bullet$ & $\bullet$ & $\bullet$ \\
Sources of finance (T) & $\times$ & $\times$ & $\bullet$ & $\times$ \\
Mission statements (T) & $\bullet$ & $\bullet$ & $\times$ & $\times$ \\
Published codes of ethics (S) (T) & $\bullet$ & $\bullet$ & $\times$ \\
\hline
\end{tabular}

Notes: Participatory monitoring (P), self-regulation (S), transparency (T), consistently implemented $(\bullet, 1$ pt.), irregularly implemented (o, 0.5 pt.) not implemented at all ( $\times, 0$ pt.).

tion of El Diario, whose Editor-in-Chief reports annually on the balance sheet of his outlet, consistent with a business model in which reader subscriptions meant $43.4 \%$ of the total revenues for 2018 .

As part of the commitments made with The Trust Project consortium in 2018, the two print media, El País and El Mundo, make their mission statements and codes of ethics fully visible. According to the interviewees, this information has always been collected in the print edition of their style books, but so far it had hardly been accessible from the web. On the other hand, El Confidencial and El Diario mention in some of their articles the existence of deontological codes that govern their activity, but do not believe that it is necessary to make them available to the public. While El Confidencial remains opaque in terms of its values, El Diario opts for an original solution to unveil the set of principles that define its editorial line: a section called 'Focos' ('Focal points') that offers over twenty issue categories that, as tags, define the core and editorial priorities of the outlet.

\subsection{During Production}

The four outlets recognize the importance of showing the author's byline on each digital article, except for those that come from one or several news agencies and those that have their origin in press releases and official sources, which are usually signed using the name of the newspaper. Every article shows in a transparent way the timestamps of the latest updates and all the bylines are enriched with hypertext that offers the possibility of informing oneself further about the authors: the most frequent option is to link the bylines to the profiles of these journalists on Twitter and/or their history of previous publications. However, the profiles that explore the identity of journalists have only been developed in El Diario, where authors also have their own space that includes a small biographical outline and their past interventions in the comment boxes.

The use of hypertext to link to sources is frequent in the four outlets, both in the news body and in small pull quotes. Although the main purpose of hypertext is to link to related content within the outlet's site, the remarkable presence of links to original sources such as external websites or even documentary sources-such as judicial decrees or sentences-that occasionally are embedded in the articles to facilitate their consultation. With regard to offering precise links to sources, at El País "not only is there not a policy against it, but [its use] is encouraged", while at El Mundo there is, in general, "a healthy tradition of linking" even to the competition, although our interviewee perceives that, over time, fewer and fewer links are used. Furthermore, print outlets occasionally suffer a hypertextual impoverishment during the night, when the texts from the printed edition replace those that have been written for the website on the previous day and their original links are not restored, which undoubtedly weakens accountability. At the digital natives, there are no impediments to link to any type of external content, as El Diario's interviewee corroborates: "On the contrary, if the editor in charge does not link, he will receive a warning to do so." In the same vein, the interviewee of El Confidencial emphasizes that it is an outlet made mostly by professionals who had a blog when they were young and conceive of that proceeding as something "natural," although there are always "people who are more prone to insert them and people who are less."

Only the native outlets keep active newsroom blogs. The Blog de la Redacción of Eldiario.es announces new projects, initiatives and events organized by this outlet. For its part, in El Confidencial this space, under the name 'En contacto' ('In contact'), usually brings together corporate information, audience records and other business achievements not always connected to accountability. In contrast, at the legacy outlets they recognize that transparency initiatives aimed at showing the interiors of journalistic work emerge without planning or being fit into specific spaces, i.e., spontaneously, and when favorable informative situations arise. For example, El Mundo published a video of the editorial meeting in which the publication of the photo of Aylan Kurdi, the Syrian child drowned on the Turkish coast in 2015 during the migration crisis in Europe, was discussed.

As seen in Table 2, the sections in which these outlets propose pieces that involve readers in collaborative contents are unusual and consulted journalists confirm that they emerge more as specific initiatives than as regular spaces for professional-citizen collaboration. Except for the op-eds and collaborative interviews (or 'ask the expert' features) in their different formats and platforms, which enjoy a certain vitality, these participatory pieces 
Table 2. Level of implementation of MAls that have an impact during news production.

\begin{tabular}{|c|c|c|c|c|}
\hline MAI & ElPais.com & ElMundo.es & Eldiario.es & ElConfidencial.com \\
\hline Authorship (byline)/profiles ( $\mathrm{T}$ ) & $\bullet$ & $\bullet$ & $\bullet$ & $\bullet$ \\
\hline Timestamps/updates ( $\mathrm{T})$ & $\bullet$ & $\bullet$ & $\bullet$ & $\bullet$ \\
\hline Links to sources $(T)$ & $\bullet$ & $\bullet$ & $\bullet$ & $\bullet$ \\
\hline Newsroom blogs (T) & $x$ & $x$ & $\bullet$ & $\bullet$ \\
\hline Collaborative contents (P) & ० & ○ & o & o \\
\hline
\end{tabular}

Notes: Participatory monitoring (P), transparency (T), consistently implemented $(\bullet, 1$ pt.), irregularly implemented $(0,0.5$ pt.) not implemented at all ( $\times, 0 \mathrm{pt}$.).

are characterized as secondary or as a support for other articles driven by these news media. The interviewees asseverate that little user-generated content is proactively requested and, when it is produced, usually revolves around soft news or is motivated by the stress of crisis news coverage-terrorist attacks, natural disasters, etc. The enormous effort involved in managing, filtering and editing readers' collaborations is the main factor that slows their implementation.

\subsection{After Publication}

Regarding contact opportunities, the interviewees agree to giving great importance to the possibility that the audience can contact journalists through the traditional methods established on the website (web forms and e-mail) and they consider that these readers are more loyal and have taken more effort to contact than those who do it through social media. While El País provides the generic e-mail addresses of each of the sections, El Mundo prefers to centralize the contact through a single e-mail address/form, which requires of them a great management effort: "It is necessary to filter. Of every one hundred mails you get...you find a 'gold nugget."' In the natives, the author contact opportunities are more specific: each editor of El Confidencial can be contacted individually through a simple web form and El Diario journalists show their e-mail address on their profiles. Often these professionals receive congratulations from readers through the above channels, which strengthens their self-esteem: "Suddenly, feeling that you have written something that someone has liked or has been useful...reminds you who you are writing for and that there are people there," declares the audience manager of El País.
Of the four analyzed outlets, only the native EI Diario offers a correction button to its readers (see Table 3 ), called 'He visto un error' ('I have seen an error'). Even so, all respondents state that the reception of corrections detected by the audience is constant, of a heterogeneous nature and notified through a wide variety of means, as is explained at El Mundo: "People read the website in many ways and [corrections] can arrive in a thousand ways," so audience engagement teams remain alert to comments, e-mails and social media to correct any errors. As the interviewees confirm, all problems localized are amended, especially errata and factual inaccuracies. Nevertheless, when the corrections suggested by readers collide with editorial decisions, such as those related to informative approaches or priorities, rectifications take hold less. Most of the studied outlets even attach a corrigendum to the piece, which reports that it has been updated once rectified.

Only El País has an ombudsman that addresses complaints about the journalistic norms and values of the newspaper and delves into the mistakes, now in an innovative Q\&A format. In the opinion of the head of audience engagement, his figure "has a lot of value" thanks to his "total autonomy to evaluate, analyze and criticize the work of the newspaper," since he receives from the Editor-in-Chief "the power to dissent, to be able to do self-criticism." In the past, El Diario had a "community ombudsperson,' now inactive: "We are not the kind of news outlet that needs to have a permanent ombudsperson present in the newsroom." It just so happened that this instrument was overlapped by the variety of accountability poles offered by the outlet and, in addition, the professionals who held the position were involved in other projects, which contributed to the initial enthusiasm gradually diminishing.

Table 3. Level of implementation of MAls that have an impact after publication.

\begin{tabular}{lcccc}
\hline MAl & ElPais.com & ElMundo.es & Eldiario.es & ElConfidencial.com \\
\hline Contact opportunities (P) & $\bullet$ & $\bullet$ & $\bullet$ & $\bullet$ \\
Correction buttons (P) & $\times$ & $\times$ & $\times$ & $\times$ \\
Ombudsperson (S) (T) (P) & $\bullet$ & $\times$ & $\bullet$ & $\times$ \\
Comments (P) & $\bullet$ & $\bullet$ & $\bullet$ & $\bullet$ \\
Letters to editors (P) & $\bullet$ & $\times$ & $\times$
\end{tabular}

Notes: Participatory monitoring $(\mathrm{P})$, self-regulation $(\mathrm{S})$, transparency $(\mathrm{T})$, consistently implemented $(\bullet, 1 \mathrm{pt}$.$) , irregularly implemented$ (o, 0.5 pt.) not implemented at all $(\times, 0$ pt.). 
With regard to comments as MAls, they are weakened at the individual level by the unequal penetration of the habit of reading the readers' comments at the analyzed outlets. It is a spontaneous practice that depends exclusively on the will of the journalists and is often displaced by other more pressing tasks for them: "If they stop doing it to get a scoop, it's understandable," adds El Mundo's manager. As interesting as it may be, inviting them to interact may not be enough and forcing them to do so is not an option either. Therefore, it is more complicated to get journalists to write and take part in the debate in the comment boxes, despite the fact that this routine has sometimes been promoted from management positions. At El Confidencial "many editors are not very supportive of reading the comments on their pieces, but the audience engagement team does read them." At Eldiario.es, on the contrary, they defend the fact that "comments are read...they are read a lot," although "not so much is replied."

Our interviewees point out that the climate of debate on the comments varies considerably according to the section to which the news content in question belongs. The most optimistic perspectives on the value of this instrument come from legacy outlets, such as El Mundo, where readers are perceived to make interesting contributions, especially in the sections related to qualified issues (such as Business). There, the readers who participate "know the subject and, sometimes, they are the ones who criticize you...based on judgments and reasons," instead of using, for example, an intern as a scapegoat. In contrast, at El Confidencial it is stated that "comments are dying because young people do not leave them" on the website, but on public or private social network platforms. Likewise, it is acknowledged that the majority of comments are written by readers of an age range over 40 years, so it is considered a mechanism that is winding down: "I have not left a comment in my entire life, although I do comment on the news everyday," says this audience manager in his early 30 s.

The challenge of moderating readers' comments and achieving a favorable environment for participatory monitoring to be harmonious and effective is assumed from different perspectives and strategies based on postmoderation and on applying participation policies that have been adapted to create the appropriate atmosphere. The two studied print outlets have an important influx of comments, so they use external moderation companies that usually work with word filters to separate the uncivil comments from valuable contributions. Thus, their audience engagement teams are only responsible for decisions of a last resort, such as the application of warnings, sanctions or expulsions of unruly users or the recognition of the most reliable ones-marked as 'outstanding user' at El País or as 'partner' at El Diario. Conversely, native outlets, which receive a lower flow of comments, keep this management internalized and entrust much of the daily work to the voting and reporting systems that are available to users. In any case, we have detected a cer- tain tendency on the part of the interviewees to value comments with restrained optimism, and almost always compared them to what they perceive to exist in the competition: "bearable," "tolerable" and even that "it may be worth it" are some of the ways in which they refer to this instrument.

Letters to editors are a feedback instrument as accepted as they are questioned. El País defends them as an identity sign, so it not only publishes these missives online, but encourages readers to send them via e-mail. Meanwhile, El Mundo values these texts and keeps them active in their printed edition, but has stopped publishing them in its free-access online version. In its almost two decades of online history, El Confidencial has never used letters to editors as a way to spiritually distance themselves from the old print media. In comparison, El Diario has tried to rejuvenate this instrument through a blog, 'El Diario responde' ('El Diario responds'), that, in addition to making readers dissatisfactions visible, incorporates some characteristic features of transparency and pedagogy of the ombudsperson. There is the opportunity to ask "essentially for questions about the internal functioning of the newspaper" that the Editor-in-Chief and other relevant staff members respond to, offering explanations or endorsing their way of proceeding regarding newsmaking.

Although the presence on social media of news professionals and organizations contributes in ways that should not be underestimated before and during production, it is undoubtedly after publication when readers' activities are more used for accountability purposes: "They help us a lot with self-criticism....They encourage us to set the standards much higher and to look at ourselves less complacently," says the interviewee from El País. In general, monitoring reactions on social media is mentioned as an interaction more supported by journalists than reading the comments on the website, even in spite of the occasional harassment that some of them suffer. Regarding their perceptions of social media criticism, they characterize Twitter users as the most demanding and scrupulous, but also those who know the news brands they follow best. At the time, they conceive Facebook users as a collective less interested in quality news, but who come to make contact through this platform even more than by e-mail, as is the case at El País.

The strategies for the management of organizational profiles on social media focus on content dissemination due to the commercial obligations that push them to get web traffic, which are imperative and put ahead of more participatory contents that would improve community bonds. The audience engagement teams of the legacy news media, the largest ones, experience difficulties in getting a common publishing style to be respected in the extensive catalog of organizational profiles they support and whose management is partly delegated. Native outlets, on the other hand, tend to centralize the management of their social media profiles on the audience engagement teams themselves. 
Although none of the analyzed outlets has issued social media guidelines, the audience managers at the legacy outlets are the most open to regulate journalists' behavior, especially if these regulations are agreed on by the staff and are not imposed from above. At El País (565 individual profiles registered on Twitter) and El Mundo (326), the interviewees recognize the existence of concerns derived from the editors' presence on social media in the past, and it is pointed out that the generational differences, more pronounced in their staffs, are a significant aspect to understand this issue. On the other hand, at El Diario (164) and El Confidencial (141) they do not consider adopting any regulation: behavior of their professionals emerges in an organic way "guided by common sense," something that has avoided important incidents in the past.

\section{Discussion and Conclusions}

Our findings show that the online MAls implemented in the leading digital news media in Spain maintain a propensity for transparency; and while the analyzed legacy outlets preserve better the essences of selfregulation, both types of media maintain a similar commitment to participatory instruments, as seen in Figure 1 and Table 4. The two outlets that have the largest audience engagement teams lead the implementation of MAls that have an impact on news production, led by the native Eldiario.es and followed closely by the digital edition of the newspaper El País (see Figure 2 and Table 5). The scarcity of instruments used by ElConfidencial.com in the first and last phases or by EIMundo.es in the final stage suggest that, in effect, media accountability should not be observed as "a matter of a caricatural opposition of fossilized media brands versus agile and creative media startups" (Filloux, 2014), but rather it depends on structural factors of a diverse nature-cultural, technological, economic and even sociodemographic-that we have identified and condition the performance of MAls.

We have found that the two legacy news media have articulated a greater number of instruments to make their transparency as media actors effective before production (see Figure 3 and Table 6), especially when making public the codes of ethics that guide their activity. At the same time, revealing the sources of finance is an unusual transparency commitment that only Eldiario.es assumes, in coherence with the important financing it receives directly from its readers. Substantial differences have been detected in the ways of understanding production transparency, as the digital natives have systematized and normalized it more than the legacy outlets, mainly through newsroom blogs that are not free from shortcomings, given that the commercial and promotional aspects coexist and sometimes take up more space than genuine revelations about editorial processes, a characteristic that has been also highlighted in contem-

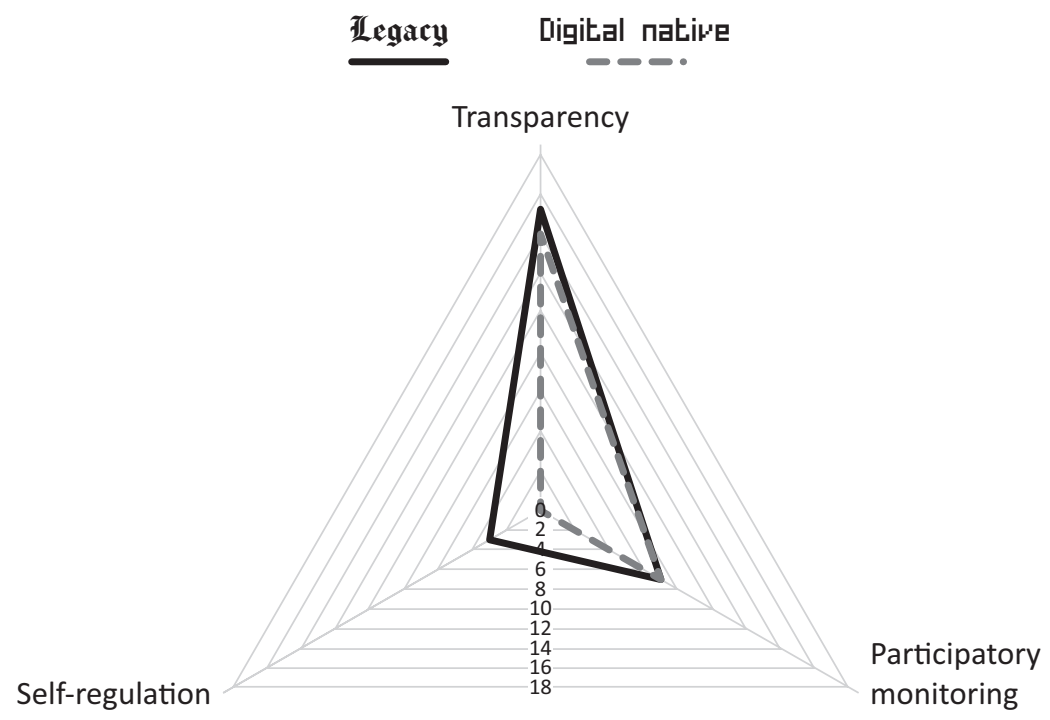

Figure 1. Kiviat diagram representing the scores obtained by each type of media according to the nature of their implemented MAls. Source: Authors.

Table 4. Scores obtained by each type of media according to the nature of their implemented MAls.

\begin{tabular}{lcr}
\hline Nature of implemented MAls & Legacy outlets & Digital native outlets \\
\hline Self-regulation (S) & 3 & 0 \\
Transparency (T) & 15 & 14 \\
Participatory monitoring (P) & 7 & 7 \\
\hline
\end{tabular}

Notes: Participatory monitoring $(\mathrm{P})$, self-regulation $(\mathrm{S})$, transparency $(\mathrm{T})$. 


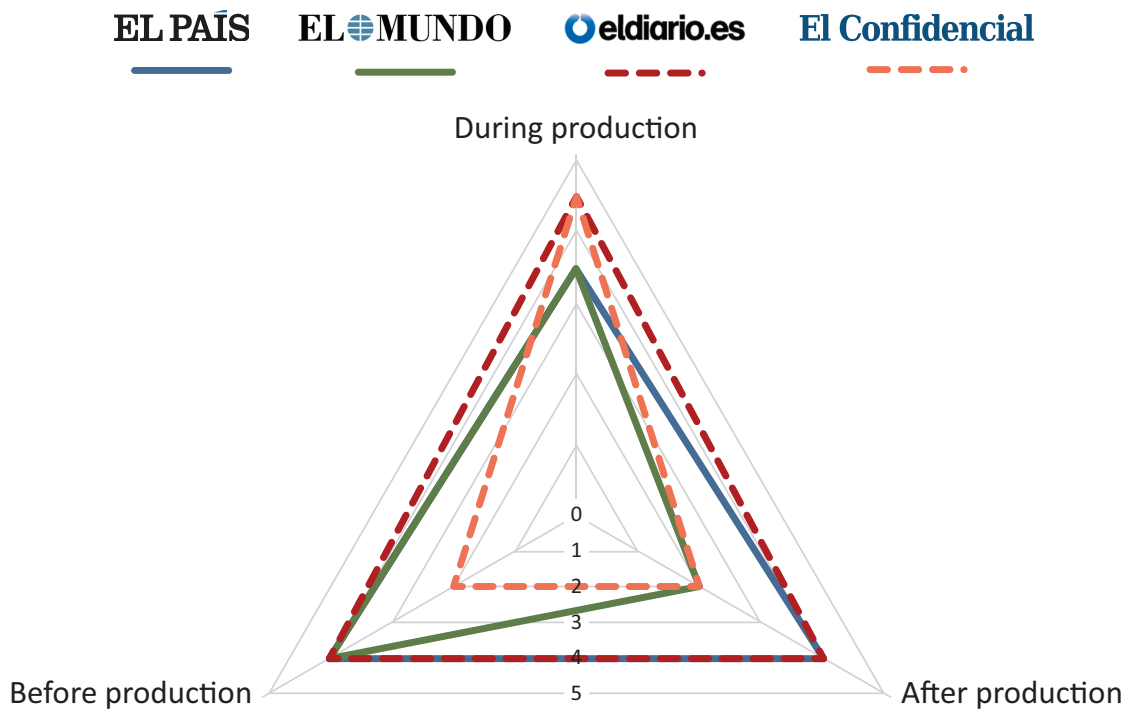

Figure 2. Kiviat diagram representing the scores obtained by each media outlet according to their implemented MAls in the three phases of news production. Source: Authors.

Table 5. Scores obtained by each media outlet according to their implemented MAls in the three phases of news production.

\begin{tabular}{lcccc}
\hline News production phase involved & EIPais.com & ElMundo.es & Eldiario.es & ElConfidencial.com \\
\hline Before production & 4 & 4 & 4 & 2 \\
During production & 3,5 & 3,5 & 4 & 4 \\
After publication & 4 & 2 & 4 & 2 \\
\hline
\end{tabular}

Before production


poraneous works (García-Avilés, 2019). Although the culture of linking to sources is widespread, in the online editions of newspapers it can be conditioned by technical determinants derived from the two publishing cycles with which they work.

Likewise, regardless of the nature of the outlet and the size of the staff, conversations with audience managers delineate an outlook in which the high labor demands of journalists make it difficult to undertake collaborative initiatives that generate truly valuable usergenerated content for a more open and higher quality news discourse. For this same reason, although the audience teams of all outlets remain attentive after publication, it is common that attention to feedback has a low priority among the elementary work routines of the majority of journalists. Skepticism toward comments as MAls contributes to this, although the smaller communities of the digital natives enjoy a more thorough management than the legacy media communities, necessarily managed with external support.

The protection of journalistic authority determines which errors pointed out by readers are corrected: the factual and formal ones are frequently rectified but journalists are reluctant to accept external interferences in their editorial decisions, something that can be conceived as a way to legitimize their role and protect their autonomy (Carlson \& Lewis, 2015; Eide, 2017). Even so, there is certain organizational interest for accountability to occur within the media domain and not in external spaces where journalists do not have control over the information flows, which is distinctive from their occupational ideology (Lewis, 2012). According to the journalistic field theory, that understands the profession as an evolving social construction (Carlson, 2018), these findings present journalists as agents that try to preserve journalistic boundaries. In the opposite direction, it is openly recognized that professionals monitor and are more responsive on social media than on the outlet's website, something that contrasts with the short-termist organizational strategy on those platforms, characterized by a diffusion logic and a focus on web traffic generation over any attempt to consolidate bonds with the audience. Consequently, the adoption of social media guidelines is not a priority concern in these newsrooms, especially in the digital native outlets that employ younger journalists accustomed to working in digital environments.

To sum up, we have verified that the most essential instruments of transparency seem to be established in the leading Spanish digital news media, although the traditional self-regulation instruments, less implemented, have possibilities of revitalization thanks to the inclusion of innovative features. Consolidating strategies to achieve a participatory monitoring that benefits the integrity of these outlets is a great challenge for which it is necessary to continue working on improving the functioning of the internal communities of readers without neglecting that of the external ones. For this, it will still be relevant to bet on teams specialized in audience en- gagement, provided with sufficient resources to properly manage citizen inputs and willing to motivate staff by highlighting the importance of public accountability initiatives.

As a contribution, this study has showed that media accountability is more a cultural, structural, and unique question to the organization than we might have assumed in the past. According to our results, media system comes out as a key factor to better understand this process. However, as a limitation of the study we should address that results are based on the Spanish news media landscape, that is considered a polarized pluralistic model (Hallin \& Mancini, 2004). Future studies should extend their research on accountability and replicate it among other countries, with a different media and political system, in order to test in what extent media and political system can be a crucial factor among other cultural contexts. In addition, this study could be enriched with future analyses that take into account the business nature of the news organization, in order to verify whether its structure, funding model or proprietorship affect the results. Further extension of this descriptive study, from methodological aspects, could be considered in future research by adding a joint interpretation of content analysis data and journalists interviews in a complementary manner. Similarly, a survey of readers' opinions about their interest in participating to hold these outlets responsible could be relevant to weigh their role in accountability processes.

\section{Conflict of Interests}

The authors declare no conflict of interests.

\section{References}

Alsius, S., Mauri-Ríos, M., \& Rodríguez-Martínez, R. (2011). Spain: A diverse and asymmetric landscape. In T. Eberwein, S. Fengler, E. Lauk, \& T. Leppik-Bork (Eds.), Mapping media accountability in Europe and beyond (pp. 155-167). Cologne: Halem.

Alsius, S., Rodríguez-Martínez, R., \& Mauri-Ríos, M. (2018). Spain: New formats and old crises. In T. Eberwein, S. Fengler, \& M. Karmasin (Eds.), The European handbook of media accountability (pp. 243-250). New York, NY, and London: Routledge.

Alsius, S., \& Salgado, F. (2010). La ética informativa vista por los ciudadanos: Contraste de opiniones entre los periodistas y el público [The information ethics seen by citizens: Contrast of opinions between journalists and the public]. Barcelona: UOC.

Asociación de la Prensa de Madrid. (2015). Informe anual de la profesión periodística 2015 [Annual report on the journalistic profession 2015]. Madrid: Asociación de la Prensa de Madrid.

Bertrand, C. J. (2000). Media ethics and accountability systems. New Brunswick and London: Transaction Publishers. 
Bhakta Acharya, B. (2015). Media accountability on digital platforms: The role of audience. Amity Journal of Media \& Communication Studies, 5(1/2), 81-92.

Campos-Domínguez, E., \& Redondo-García, M. (2016). Meta periodismo y transparencia informativa en el periodismo del siglo XXI [Meta-journalism and media transparency in journalism of the 21st century]. OBETS: Revista de Ciencias Sociales, 10(1), 185-209.

Carlson, M. (2018). Boundary work. The International Encyclopedia of Journalism Studies. https://doi.org/ 10.1002/9781118841570.iejs0035

Carlson, M., \& Lewis, S. C. (Eds.). (2015). Boundaries of journalism: Professionalism, practices and participation. New York, NY, and London: Routledge.

Casero-Ripollés, A. (2016). El periodismo emprendedor ante el reto de su consolidación [The entrepreneurial journalism in front of its consolidation challenge]. Anuario ThinkEPI, 10, 203-208.

Chaparro-Domínguez, M. A., Suárez-Villegas, J. C., \& Rodríguez-Martínez, R. (2019). Media accountability and journalists: To whom do Spanish professionals feel responsible? Journalism Practice. https://doi. org/10.1080/17512786.2019.1655470

Craft, S., Vos, T. P., \& David Wolfgang, J. (2016). Reader comments as press criticism: Implications for the journalistic field. Journalism, 17(6), 677-693.

Domingo, D. (2015). Fostering and moderating citizen conversations. In L. Zion, \& D. Craig (Eds.), Ethics for digital journalists: Emerging best practices (pp. 159-173). New York, NY, and London: Routledge.

Eide, M. (2017). Digital transparency and accountability. In B. Franklin \& S. A. Eldridge II (Eds.), The Routledge companion to digital journalism studies (pp. 253-262). New York, NY, and London: Routledge.

Fengler, S. (2012). From media selfregulation to 'crowdcriticism': Media accountability in the digital age. Central European Journal of Communication, 5(2), 175-189.

Fengler, S., Eberwein, T., Mazzoleni, G., Porlezza, C., \& Russ-Mohl, S. (Eds.). (2014). Journalists and media accountability: An international study of news people in the digital age. New York, NY: Peter Lang.

Filloux, F. (2014, November 24). Hard comparison: Legacy media vs. digital native. Monday Note. Retrieved from https://mondaynote.com/hardcomparison-legacy-media-vs-digital-native6adf558ff308

Friend, C., \& Singer, J. B. (2015). Online journalism ethics: Traditions and transitions. New York, NY, and London: Routledge.

García-Avilés, J. A. (2014). Online newsrooms as communities of practice: Exploring digital journalists' applied ethics. Journal of Mass Media Ethics, 29(4), 258-272.

García-Avilés, J. A. (2019). Examining media accountability in online media and the role of active audiences. In T. Eberwein, S. Fengler, \& M. Karmasin (Eds.), Media accountability in the era of post-truth politics (pp. 270-283). New York, NY, and London: Routledge.
García-Avilés, J. A., \& Arias Robles, F. (2016). Evolución de los cibermedios en España: Claves de innovación [Evolution of digital news media in Spain: Keys for innovation]. In C. Sádaba Chalezquer, J. A. GarcíaAvilés, \& M. P. Martínez-Costa (Eds.), Innovación y desarrollo de los cibermedios en España (pp. 63-71). Madrid: Eunsa.

Gold, H., \& Pompeo, J. (2017). New York Times eliminates its public editor. Politico. Retrieved from https://www.politico.com/story/2017/05/31/newyork-times-public-editor-239000

Goodman, L. A. (1961). Snowball sampling. Annals of Mathematical Statistics, 32(1), 148-170.

Hallin, D. C., \& Mancini, P. (2004). Comparing media systems: Three models of media and politics. Cambridge: Cambridge University Press.

Heikkilä, H., Domingo, D., Pies, J., Głowacki, M., Kuś, M., \& Baisnée, O. (2012). Media accountability goes online: A transnational study on emerging practices and innovations (MediaAcT Working Paper 14/2012). Tampere: Journalism Research and Development Centre.

Hernández Sampieri, R., Fernández Collado, C., \& Baptista Lucio, P. (2010). Metodología de la investigación [Research methodology]. Mexico: McGraw-Hill.

Krippendorff, K. (2004). Content analysis: An introduction to its methodology. Thousand Oaks, CA: Sage.

Lewis, S. C. (2012). The tension between professional control and open participation. Information, Communication \& Society, 15(6), 836-866.

Masip, P., \& Suau, J. (2014). Audiencias activas y modelos de participación en los medios de comunicación españoles [Active audiences and participation models in Spanish media]. Hipertext.net, 12. http://dx.doi. org/10.2436/20.8050.01.3

Mauri-Ríos, M., \& Ramon-Vegas, X. (2015). Nuevos sistemas de rendición de cuentas de la información periodística: Exploración del escenario online español [New media accountability systems: Exploration of the Spanish online environment]. El Profesional de la Información, 24(4), 380-389.

McQuail, D. (2003). Media accountability and freedom of publication. Oxford: Oxford University Press.

Min, Y. (2015). Accountability of the media. In W. Donsbach (Ed.), The concise encyclopedia of communication (pp. 1-2). Malden, MA, Oxford and Chichester: John Wiley.

Negredo, S. (2019). Cinco periódicos, tres medios nativos digitales y dos televisiones, los más visitados para informarse online [Five newspapers, three native digital media and two television channels, the most visited to get news online]. Digital News Report Spain. Retrieved from https://www.digitalnewsreport.es/ 2019/cinco-periodicos-tres-nativos-digitales-y-dostelevisiones-los-mas-visitados-para-informarseonline-en-espana

Palau-Sampio, D. (2017). Dealing with viewers' complaints: Role, visibility and transparency of PSB om- 
budsmen in ten European countries. Observatorio, 11(4), 122-138.

Pastor, L. (2011). Periodismo zombi en la era de las audiencias participativas: La gestión periodística del público (II) [Zombie journalism in the era of participatory audiences: The journalistic management of the public (II)]. Barcelona: Editorial UOC.

Rodríguez-Martínez, R., Mauri-Ríos, M., \& Fedele, M. (2017). Criticism in journalism as an accountability instrument: The opinion of Spanish journalists. Communication \& Society, 30(1), 57-72.

Rojas Torrijos, J. L., \& Ramon-Vegas, X. (2017). Accountability en las redes sociales: Libros de estilo en continua evolución y retroalimentación a través de Twitter [Accountability in social networks: Ever-evolving stylebooks and feedback through Twitter]. Revista Latina de Comunicación Social, 72, 915-941.

Salaverría, R., Martínez-Costa, M. P., \& Breiner, J. (2018). Mapa de los cibermedios de España en 2018: Análisis cuantitativo [Map of digital news media at Spain in 2018: Quantitative analysis]. Revista Latina de Comunicación Social, 73, 1034-1053.

Suárez-Villegas, J. C. (2015). Nuevas tecnologías y deontología periodística: Comparación entre medios tradi- cionales y nativos digitales [ICT and journalistic deontology: A comparative analysis between traditional and digital native media]. El Profesional de la Información, 24(4), 390-395.

Suárez-Villegas, J. C., Rodríguez-Martínez, R., Mauri-Ríos, M., \& López-Meri, A. (2017). Accountability y culturas periodísticas en España: Impacto y propuesta de buenas prácticas en los medios de comunicación españoles (MediaACES) [Accountability and media systems in Spain: Real impact and good practices in Spanish media]. Revista Latina de Comunicación Social, 72, 321-330.

Ward, S. J. A. (2013). Why hyping transparency distorts journalism ethics. MediaShift. Retrieved from http://mediashift.org/2013/11/why-hypingtransparency-distorts-journalism-ethics

Ward, S. J. A. (2015). Invention of journalism ethics: The path to objectivity and beyond. Montreal, Kingston, London and Chicago, IL: McGill-Queen's University Press.

Wu, L. (2017). Meet the new players: A study of digital native journalists and journalistic professionalism (Doctoral dissertation). University of North Carolina at Chapel Hill, Chapel Hill, NC.

\section{About the Authors}
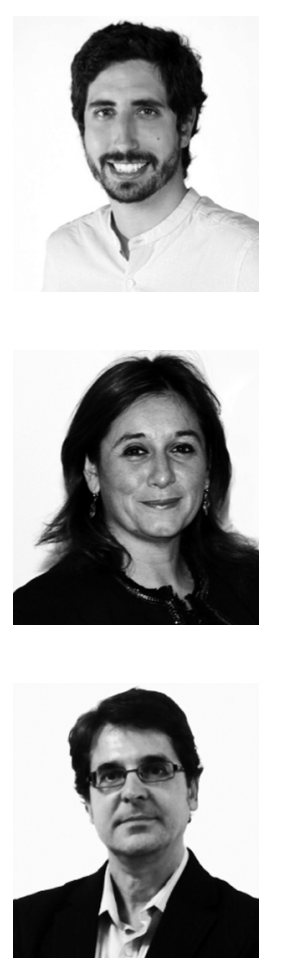

Pedro-Luis Pérez-Díaz (PhD, Catholic University of Murcia) is an Assistant Professor in the Department of Journalism at Catholic University of Murcia, where he is a member of the Communication, Politics, and Image Research Group, a multidisciplinary team primarily devoted to studies on political communication, journalistic mediation, and image consulting. His main research interests lie in the field of civic/participatory journalism in digital contexts, with a focus on analyzing the public discourses that media, citizens, and political actors share on social media in contemporary democratic societies. He tweets from @pedroluis.

Rocío Zamora Medina (PhD, University of Navarra) is an Associate Professor in the Department of Communication and Information at the University of Murcia, where she is a member of the Social Communication, Culture, and Technology Research Group. Her main research interests lie in the field of political communication and online campaigning, with a focus on analyzing communication strategies based on the use of personal information in social media contexts. She tweets from @rzamoramedina.

Enrique Arroyas Langa (PhD, Catholic University of Murcia) is a member of the Communication, Politics, and Image Research Group. He researches at the intersection of media and politics, focusing on the relationship between news media and political discourse. Much of his work uses rhetoric methods to study political discourses, including the role of social media in the rise of populist movements and other contemporary challenges to democracy. Currently, he is an Associate Professor at the Catholic University of Murcia. He tweets from @enriquearroyas. 